\title{
The Effect of Employee Engagement on Organizational Citizenship Behaviour: An Empirical Study on an Egyptian University
}

\author{
Amira Abd-El Aziz Mohamed Riad ${ }^{1}$, Eglal Hafez ${ }^{1}$, Eahab Elsaid ${ }^{2} \&$ Nicole Taylor $^{2}$ \\ ${ }^{1}$ Faculty of Commerce, Ain Shams University, Egypt \\ ${ }^{2}$ Odette School of Business, University of Windsor, Canada \\ Correspondence: Eahab Elsaid, Odette School of Business, University of Windsor, Canada. E-mail: \\ elsaid@uwindsor.ca
}

Received: June 23, 2019

Accepted: August 5, 2019

Online Published: August 6, 2019

doi:10.5430/bmr.v8n3p1

URL: https://doi.org/10.5430/bmr.v8n3p1

\begin{abstract}
The goal of the study is to examine the effect of Employee Engagement (EE) as an independent variable on Organizational Citizenship Behaviour (OCB) as a dependent variable. The study was carried out in an Egyptian public university (Ain Shams University). The data was collected through questionnaires distributed to faculty members. The sample consisted of 318 questionnaires valid for statistical analysis. The methodology used was regression analysis, and structured equation model (path analysis). The study found a positive direct effect of EE on OCB.
\end{abstract}

Keywords: Egypt, Employee Engagement, Organizational Citizenship Behaviour, Path Analysis

\section{Introduction and Literature Review}

Organizations have been focusing on the role of management in how it relates to how committed and loyal employees are to their jobs. In this structural context, organizations have been putting great emphasis on behaviours that might influence organizational performance and effectiveness. As a result, organizations attempt to hire staff who perform their formal role requirements, in addition to going above and beyond their job duties. This paper examines two of the important behaviours that Human Resource Developers (HRD) have recently focused on due to their major role in the development and advancement of the organization. These two behaviours are EE and OCB.

The concept of EE is rapidly gaining recognition as a comparison measurement in organizations (Little and Little, 2006). To say the least, EE is one of the drivers of success for any organization (Lakshmi, 2012). OCB has been the focus of attention for management researchers (Podsakoff et al., 2000; Organ and Ryan, 1995; Organ, 1997) since Organ (1988) proposed that OCB could have an effect on the performance of the individual and the organization and thus, it is desirable because it deals with major variables such as: organizational effectiveness and organizational productivity.

There has been a large amount of previous research that has studied the following aspects of EE: the concept and evolution of EE (Kaliannan et al., 2015; Maslach, Schaufeli and Leiter, 2001; Schaufeli and Bakker, 2004). How to measure and create models for EE (Harter et al., 2002; Saks, 2006; Shuck et al., 2011; Soeib et al., 2013). The different dimensions of EE (Ariani, 2013; Bakker, 2005; Brown and Leigh, 1996; Cooper-Hakim and Viswesvaran, 2005; Langelann et al., 2006; Llorens et al., 2007; Mauno, Kinnunen and Ruokolainen, 2007; Schaufeli et al., 2006). The main drivers of EE (Markos and Sridevi, 2010; Shaw, 2005). The relationship between EE and the following concepts: job burnout (Babcock-Roberson and Strickland, 2010; Gonzalez-Roma, Schaufeli and Bakker, 2006), job involvement (Mauno, Kinnunen and Ruokolainen, 2007), job satisfaction (Ariani, 2013), self management (Breevaart, Bakker and Demerouti, 2014; Murphy and Ensher, 2001; Raabe, Frese and Beehr, 2007) and organizational success (Avery et al., 2007; Kaliannan and Adjovu, 2015). The different antecedents (predictors) of EE such as: job fit (Resick, Baltes and Shantz, 2007; Shuck, Reio and Rocco 2011), rewards and recognition (Sahoo and Mishra, 2012), perceived organizational/supervisory support (Bates, 2004; Rasheed, Jehanzeb, and Rasheed, 2013; Rhoades and Eisenberger, 2002), organizational justice (Colquitt, 2001), job characteristics (May, Gilson and Harter, 2004), organizational commitment (Ariani, 2013; Soieb, Othman and D'Silva, 2013) and job satisfaction (Abraham, 2012). The different consequences of EE such as: turnover intent (Harter, Schmidt and Hayes, 2002, Saks, 2006) and discretionary behaviours (Lloyd, 2008; Macey and Schneider, 2008). 
There has also been a large amount of previous research that has studied the following aspects of OCB: the origin and evolution of OCB (Kataria, Garg and Rastogi, 2013; Mohammed, Habib and Alias, 2011; Murphy, Athanasou and King, 2002; Organ, 1988; Podsakoff et al., 2000; Zarea, 2012). The benefits of OCB (Javadi and Yavarian, 2011; Organ, Podsakoff and MacKenzie, 2006). The dimensions of OCB (Kolade, Oluseye and Omotayo, 2014; Mohammed, Habib and Alias, 2011; Zarea, 2012). The relationship between OCB and the following concepts: organizational performance (Rasheed, Jehanzeb and Rasheed, 2013; Sahafi et al., 2013), contextual performance (Ariani, 2013; Miles et al., 2002), transformational leadership behaviour (Asgari et al., 2008; Krishnan, 2005), leader-member-exchange (Ibrahim, Abd Ghani and Embat, 2013), organizational communication (Ayatse and Ikyanyon, 2012; Berger, 2008; Kandlousi, Ali and Abdollahi, 2010) and trust (Jung and Avolio, 2000). The different antecedents (predictors) of OCB such as: individual disposition (personality) (Rasheed, Jehanzeb and Rasheed, 2013; Sun, Aryee and Law, 2007), fairness perception (Lee, Kim and Kim, 2013; Muhammad, 2004), motivation (Rasheed, Jehanzeb and Rasheed, 2013; Rioux and Penner, 2001), role perception (Podsakoff et al., 2000); feedback (Bacharach, Bendoly and Podsakoff, 2001; Klein, 2003), organizational commitment (Javadi and Yavarian, 2011) job satisfaction (Aronson et al., 2005; Babcock-Roberson and Strickland, 2010; Lee and Allen, 2002) and leadership characteristics (Organ, Podsakoff and MacKenzie, 2006). The different consequences of OCB such as: its effect on evaluating performance in how it relates to promotions and pay raises (Podsakoff et al., 2000).

There is sparse previous research that examines the relationship between EE and OCB. OCB relates to EE in that it focuses on the context of employee involvement and commitment. While OCB focuses on voluntary behaviour that can be helpful to employees and organizations, EE focuses only on formal behaviours. Rukkum and Bartlett (2012) studied the relationship of EE on OCB in Thailand and found a positive significant relationship between EE and all components of OCB. Our study examines how a formal work behaviour represented in EE will lead to an informal discretionary behaviour represented in OCB. The contribution of our study is that it is conducted in Egypt which is an Arab/Middle Eastern country. Despite of a recent focus on this part of the world when it comes to management research, there is still relatively very little research conducted on Arab/Middle Eastern countries. Being able to conduct research in different geographical regions that have different cultures, tradition and religions will allow us to test whether the findings of previous research, which is mainly conducted in North America and Western Europe, can be generalized to other parts of the world. Another contribution of our study is that it is conducted in a university setting. Ain Shams University is a public not-for-profit educational institution. To the best of our knowledge, most of the past research done on EE, OCB and the relationship between EE and OCB was conducted in for profit corporations.

\section{Hypothesis Development}

\subsection{EE Dimensions}

The three main dimensions of EE are vigor, dedication and absorption. Vigor is high energy, openness to exert significant effort on the assigned task, the ability not get tired easily, and resilience when faced with difficulties (Ariani, 2013; Bakker, 2005). Dedication is a significant investment in the task, getting excited about the job, and sense of joy and contentment (Brown, 1996; Cooper-Hakim and Viswesvaran, 2005; Mauno, Kinnunen and Ruokolainen, 2007). Absorption is an experience of being consumed by the work, not realizing how quickly time passes, and not being able to leave the job (Ariani, 2013; Langelann et al., 2006; Llorens et al., 2007; Schaufeli, \& Bakker, 2004).

Atkinson (1964) considered vigor to be part of the motivational concept. Therefore, vigor is a main feature of engagement. As vigor is part of the motivational concept, it is crucial to know that it shares the most resemblance and characteristics with intrinsic motivation (Mauno, Kinnunen and Ruokolainen, 2007). Dedication was found to have some common characteristics with job involvement. Dedication seems to be a deeper concept than job involvement. It includes feelings of excitement, contentment and conceit, while job involvement relies mainly on the spiritual matters of the employee's job (Mauno, Kinnunen and Ruokolainen, 2007).

The final dimension of EE is absorption. Absorption was related to flow by many previous studies (González-Roma, Schaufeli, \& Bakker, 2006; Langelaan et al., 2006; Llorens et al., 2007). The significant difference between the two is that absorption takes place at work whereas flow usually takes place in any field of life, mainly personal life outside work (Mauno, Kinnunen and Ruokolainen, 2007; Schaufeli, Bakker and Salanova, 2006).

\subsection{OCB Dimensions}

The research into the dimensions of OCB dimensions started in the 1980s, where Smith, Organ and Near (1983) divided the dimensions of OCB into two categories: altruism: 'behaviour targeted specifically at helping individuals', and generalized compliance: 'behaviour reflecting compliance with general rules, norms and expectations, i.e. doing what a good employee should do'. This was modified by Organ (1988), who came up with the five main dimensions of 
OCB as altruism, conscientiousness, sportsmanship, courtesy and civic virtue (Babcock-Roberson and Strickland, 2010).

Although different classifications were presented by many researchers, Organ's distinction of the five main OCB dimensions are the most widely used and considered in various studies. Therefore, in this study we will use these five OCB dimensions: altruism, consciousness, sportsmanship, courtesy, and civic virtue.

\subsection{Hypotheses}

Hypothesis 1: Employee Engagement has a significant impact on Organizational Citizenship Behaviour for faculty members at Ain Shams University

Hypothesis 1a: Employee Engagement has a significant impact Altruism

Hypothesis 1b: Employee Engagement has a significant impact on Sportsmanship

Hypothesis 1c: Employee Engagement has a significant impact on Civic Virtue

Hypothesis 1d: Employee Engagement has a significant impact on Courtesy

Hypothesis 1e: Employee Engagement has a significant impact Conscientiousness

\section{Data Collection and Sample}

\subsection{Instruments/Questionnaire}

All items will be rated on a five point Likert scale ranging from 1 "Strongly disagree" to 5 "Strongly agree."

\subsubsection{EE Survey}

In this study, the 17-item Utrecht Work Engagement Scale (UWES), which is a three-scale self-report instrument, will be utilized to assess the engagement level of the employees (Schaufeli et al., 2002; Barkhuizen and Rothmann, 2006). UWES includes a 6-item "vigor" subscale $(1,4,8,12,15,17)$, a 5 -item "dedication" subscale $(2,5,7,10,13)$, and a 6-item "absorption" subscale $(3,6,9,11,14,16)$ (Rose, 2012).

As reported in the UWES Test Manual, the coefficient alphas which were tested with 31,916 employees from 16 countries, were acceptable for the engagement subscales ranging from: 0.81 to 0.90 for vigor, from 0.88 to 0.95 for dedication, and from 0.70 to 0.88 for absorption (Schaufeli and Bakker, 2003). Also, the confirmatory factor analyses (CFA) results support the three dimensional structures of the UWES (Schaufeli, Bakker, and Salanova 2006). Thus the reliability and validity of this measure was proven to be high and therefore will be used in our study.

\subsubsection{OCB Survey}

In this study, the 24 items of OCB scale developed by (Podsakoff et al., 1990) will be employed to measure the five types of subordinate OCB (Azar, 2018). The validity and reliability of this instrument indicates that the 24 items used to measure OCB in previous studies did successfully measure those five behaviours. The reliability reported by Podsakoff et al., (1990) for each of the five leadership behaviours indicated a Cronbach Alpha value of 0.82 for conscientiousness, 0.85 for sportsmanship, 0.70 for civic virtue, 0.85 for courtesy, and 0.85 for altruism. The OCB scale includes the following items for each of the five constructs -altruism ( 7 items), courtesy ( 2 items), sportsmanship (6 items), conscientiousness ( 4 items) and civic virtue (5 items).

Table 1 includes the Cronbach Alpha values for all the scales used for the measurement of EE and OCB. Since all of the Cronbach Alpha values are greater than 0.6, we can conclude that there is a high validity and internal consistency among the research variables tool regarding both EE and OCB.

Table 1. Reliability of Scales

\begin{tabular}{lc}
\hline Items & Cronbach's Alpha \\
\hline Employee Engagement & .733 \\
Vigor & .686 \\
1-At my work, I feel that I am bursting with energy. & .649 \\
4-At my job, I feel strong and vigorous. & .649 \\
8-When I get up in the morning, I feel like going to work. & .725 \\
12-I can continue working for very long periods at a time. & .709 \\
15-At my job, I am very resilient, mentally. & .745 \\
17-At my work I always persevere, even when things do not go well. &
\end{tabular}


$\begin{array}{lr}\text { Dedication } & .805\end{array}$

2-I find the work that I do full of meaning and purpose.

5-I am enthusiastic about my job. $\quad .724$

$\begin{array}{ll}\text { 7- My job inspires me } & .780\end{array}$

10- I am proud of the work that I do. $\quad .742$

13-To me, my job is challenging. $\quad .828$

$\begin{array}{ll}\text { Absorption } & .778\end{array}$

3- Time flies when I'm working.

6- When I am working, I forget everything else around me. $\quad .755$

9- I feel happy when I am working intensely. $\quad .762$

11- I am immersed (absorbed) in my work. $\quad .720$

$\begin{array}{ll}\text { 14- I get carried away when I am working. } & .722\end{array}$

16- It is difficult to detach myself from my job. $\quad .760$

Organizational Citizenship Behaviour

$\begin{array}{ll}\text { Altruism } & .831\end{array}$

$\begin{array}{ll}\text { 18- I willingly help others who have work related problems. } & .787\end{array}$

19- I help others who have heavy workloads. $\quad .800$

20- I help orient new people even though it is not required.

21- I am always ready to lend a helping hand to those around me. $\quad .784$

22- I help others who have been absent and are behind in their work. $\quad 825$

23- I believe in giving an honest day's work for an honest day's pay. $\quad 828$

24- I obey faculty rules and regulations even when no one is watching. $\quad 815$

Sportsmanship $\quad .672$

25- I do not abuse the rights of others. $\quad .609$

26- I consider the impact of my actions on co-workers.

$\begin{array}{ll}\text { Civic virtue } & .679\end{array}$

27- I try to avoid problems with co-workers.

28- I take steps to prevent problems with other co-workers. 651

29- I am mindful of how my behaviours affect other peoples' jobs. $\quad 665$

$\begin{array}{ll}30-\mathrm{I} \text { am one of my organization's most conscience employees. } & .710\end{array}$

$\begin{array}{ll}\text { Courtesy } & .687\end{array}$

31- I tend to make mountains of molehills. $\quad .620$

32- I always focus on what's wrong rather than the positive side. 699

33- I attend company functions that are not mandatory but help the faculty's image. $\quad 685$

34- I always find fault with what the faculty is doing. $\quad .690$

35- I am the classic "squeaky wheel" that always needs greasing.

36- I consume a lot of time complaining about trivial matters. 606 
Conscientiousness

37- I keep abreast of changes of the faculty.

38- I read and keep up with faculty's announcements, memos and so on. 607

39- Attend meetings that are not mandatory, but are considered important. 643

40- My attendance at work is above the norm. $\quad .717$

41- I do not take extra breaks.

\subsection{Research Sample}

The study population consists of faculty members at Ain Shams University. The researchers received 318 valid questionnaires for analysis out of more than 400 questionnaires that were distributed with a response rate of approximately $79.5 \%$. Table 2 includes the sample distribution according to gender, age and academic degree.

Table 2. Sample Distribution

Panel A: Sample Distribution according to Gender

\begin{tabular}{lllll}
\hline & Frequency & Percent & Valid Percent & $\begin{array}{l}\text { Cumulative } \\
\text { Percent }\end{array}$ \\
\hline Male & 104 & 32.7 & 32.7 & 32.7 \\
Female & 214 & 67.3 & 67.3 & 100.0 \\
Total & 318 & 100.0 & 100.0 & \\
\hline
\end{tabular}

Panel B: Sample Distribution according to Age

\begin{tabular}{lllll}
\hline & Frequency & Percent & Valid Percent & $\begin{array}{l}\text { Cumulative } \\
\text { Percent }\end{array}$ \\
\hline Less than 30 & 128 & 40.3 & 40.3 & 40.3 \\
30 - Less than 40 & 136 & 42.8 & 42.8 & 83.0 \\
40 - Less than 50 & 39 & 12.3 & 12.3 & 95.3 \\
50 - Less than 60 & 12 & 3.8 & 3.8 & 99.1 \\
60 \& above & 3 & .9 & .9 & 100.0 \\
Total & 318 & 100.0 & 100.0 & \\
\hline
\end{tabular}

Panel C: Sample Distribution according to Academic Degree

\begin{tabular}{lllll}
\hline & Frequency & Percent & Valid Percent & $\begin{array}{l}\text { Cumulative } \\
\text { Percent }\end{array}$ \\
\hline Teaching Assistant/ & 112 & 35.2 & 35.2 & 35.2 \\
Demonstrator & 121 & 38.1 & 38.1 & 73.3 \\
Assistant Lecturer & 16.0 & 16.0 & 89.3 \\
Assistant Professor & 51 & 8.2 & 8.2 & 97.5 \\
Associate Professor & 26 & 2.5 & 2.5 & 100.0 \\
Professor & 8 & 100.0 & 100.0 & \\
Total & 318 & & & \\
\hline
\end{tabular}

\subsection{Descriptive Statistics}

Table 3 shows the descriptive statistics (mean, standard deviation and coefficient of variation) for each of the dimensions of the independent variable EE (Panel A) and the dependent variable OCB (Panel B). 
Table 3. Panel A: Descriptive statistics for EE

\begin{tabular}{|c|c|c|c|c|}
\hline Items & Mean & Std. Dev & C.V. & Rank \\
\hline \multicolumn{5}{|l|}{ Employee Engagement } \\
\hline \multicolumn{5}{|l|}{ Vigor } \\
\hline 1-At my work, I feel that I am bursting with energy. & 3.4434 & .98327 & .285552 & 2 \\
\hline 4-At my job, I feel strong and vigorous. & 3.5377 & 1.04027 & .29405 & 3 \\
\hline $\begin{array}{l}\text { 8-When I get up in the morning, I feel like going to } \\
\text { work. }\end{array}$ & 3.1667 & 1.05700 & .333789 & 6 \\
\hline $\begin{array}{l}\text { 12-I can continue working for very long periods at a } \\
\text { time. }\end{array}$ & 3.6469 & 1.12675 & .308932 & 4 \\
\hline 15-At my job, I am very resilient, mentally. & 3.9214 & .83503 & .212942 & 1 \\
\hline $\begin{array}{l}\text { 17-At my work I always persevere, even when things } \\
\text { do not go well. }\end{array}$ & 3.4497 & 1.08429 & .314317 & 5 \\
\hline \multicolumn{5}{|l|}{ Dedication } \\
\hline 2-I find the work that I do full of meaning and purpose. & 4.2862 & .88976 & .207588 & 2 \\
\hline 5-I am enthusiastic about my job. & 4.0094 & .99996 & .249401 & 4 \\
\hline 7- My job inspires me & 3.5723 & 1.01073 & .282932 & 5 \\
\hline 10- I am proud of the work that I do. & 4.3491 & .84856 & .195113 & 1 \\
\hline 13 -To me, my job is challenging. & 4.1226 & .95352 & .231289 & 3 \\
\hline \multicolumn{5}{|l|}{ Absorption } \\
\hline 3- Time flies when I'm working. & 3.7547 & 1.08745 & .289623 & 3 \\
\hline $\begin{array}{l}\text { 6- When I am working, I forget everything else around } \\
\text { me. }\end{array}$ & 3.6415 & 1.09650 & .301111 & 5 \\
\hline 9- I feel happy when I am working intensely. & 3.3585 & 1.18233 & .352041 & 6 \\
\hline 11- I am immersed (absorbed) in my work. & 3.7799 & .98984 & .261871 & 2 \\
\hline 14- I get carried away when I am working. & 3.9340 & .89797 & .228261 & 1 \\
\hline 16- It is difficult to detach myself from my job. & 3.4823 & 1.04392 & .299837 & 4 \\
\hline
\end{tabular}

Table 3 Panel B: Descriptive statistics for OCB

\begin{tabular}{lllll}
\hline Items & Mean & Std. Dev & C.V. & Rank
\end{tabular}

Organizational Citizenship Behaviour

Altruism

18- I willingly help others who have work related problems.

19- I help others who have heavy workloads.

4.1792

3.9277

20- I help orient new people even though it is not required.

21- I am always ready to lend a helping hand to those around me.

22- I help others who have been absent and are behind in their work.

23- I believe in giving an honest day's work for an honest day's pay.

24- I obey faculty rules and regulations even when no one is watching.
4.110

4.1447

3.6226

3.9906

3.8365

\section{-}


Sportsmanship

25- I do not abuse the rights of others.

26- I consider the impact of my actions on co-workers.

$\begin{array}{llll}4.4214 & .70495 & .159441 & 1 \\ 4.1761 & .78660 & .188357 & 2\end{array}$

Civic virtue

27- I try to avoid problems with co-workers.

$\begin{array}{llll}4.3616 & .76890 & .176287 & 1 \\ 3.9843 & .82722 & .207621 & 2 \\ 3.9434 & .86097 & .218332 & 3 \\ & & & \\ 3.6604 & .88328 & .24131 & 4\end{array}$

30- I am one of my organization's most conscience employees.

28- I take steps to prevent problems with other co-workers.

\section{Courtesy}

31- I tend to make mountains of molehills.

$1.10954 \quad .472336 \quad 5$

32- I always focus on what's wrong rather than the positive side.

2.4971

$\begin{array}{lll}1.07382 & .43011 \quad 4\end{array}$

33- I attend company functions that are not mandatory but help the faculty's image.

2.9340

34- I always find fault with what the faculty is doing.

$1.08563 \quad .370021 \quad 2$

35- I am the classic "squeaky wheel" that always needs greasing.

2.5943

$\begin{array}{lll}1.00346 & .340191 \quad 1\end{array}$

36- I consume a lot of time complaining about trivial matters.

\section{Conscientiousness}

37- I keep abreast of changes of the faculty.

38- I read and keep up with faculty's announcements, memos and so on.

39- Attend meetings that are not mandatory, but are considered important.

40- My attendance at work is above the norm.

3.4403

$1.11873 \quad .376462 \quad 5$

41- I do not take extra breaks.

3.3152

$.97341 \quad .282947 \quad 2$

$1.06048 \quad .319969 \quad 4$

\subsection{Correlation Coefficients between EE and OCB Dimensions}

Table 4 represents the correlation coefficients between the EE and OCB dimensions. EE dimensions are listed as follows; $\mathrm{X}_{1}$ : Vigor, $\mathrm{X}_{2}$ : Dedication, $\mathrm{X}_{3}$ : Absorption. While, OCB dimensions are listed as follows; $\mathrm{Y}_{1}$ : Altruism, $\mathrm{Y}_{2}$ : Sportsmanship, $\mathrm{Y}_{3}$ : Civic Virtue, $\mathrm{Y}_{4}$ : Courtesy, $\mathrm{Y}_{5}$ : Conscientiousness. 
Table 4. Correlation Coefficients

\begin{tabular}{|c|c|c|c|c|c|c|c|c|}
\hline & (X1) & (X2) & (X3) & (Y1) & (Y2) & (Y3) & (Y4) & Y5) \\
\hline $\begin{array}{l}\text { Vigor } \\
\text { (X1) }\end{array}$ & 1.00 & & & & & & & \\
\hline $\begin{array}{l}\text { Dedication } \\
(\mathrm{X} 2)\end{array}$ & $0.723 * *$ & 1.00 & & & & & & \\
\hline $\begin{array}{l}\text { Absorption } \\
\text { (X3) }\end{array}$ & $0.751 * *$ & $0.691 * *$ & 1.00 & & & & & \\
\hline $\begin{array}{l}\text { Altruism } \\
\text { (Y1) }\end{array}$ & $0.467 * *$ & $0.436 * *$ & $0.470 * *$ & 1.00 & & & & \\
\hline $\begin{array}{l}\text { Sportsmanship } \\
\text { (Y2) }\end{array}$ & $0.345 * *$ & $0.392 * *$ & $0.383 * *$ & $0.597 * *$ & 1.00 & & & \\
\hline $\begin{array}{l}\text { Civic virtue } \\
\text { (Y3) }\end{array}$ & $0.362 * *$ & $0.383 * *$ & $0.389 * *$ & $0.583 * *$ & $0.677 * *$ & 1.00 & & \\
\hline $\begin{array}{l}\text { Courtesy } \\
\text { (Y4) }\end{array}$ & $-0.390 * *$ & $-0.259 * *$ & $-0.285^{* *}$ & $-0.274 * *$ & $-0.194 * *$ & $-0.125 * *$ & 1.00 & \\
\hline $\begin{array}{l}\text { Conscientiousness } \\
\text { (Y5) }\end{array}$ & $0.409 * *$ & $0.359 * *$ & $0.442 * *$ & $0.475^{* *}$ & $0.362 * *$ & $0.455^{* *}$ & $-0.182 * *$ & 1.00 \\
\hline
\end{tabular}

** indicates significance at the 0.01 level, * indicates significance at the 0.05 level

\section{Methodology and Findings}

Regression analysis was used to find the effect of EE on each of the five main dimensions of OCB independently. Table 5 shows the kind and degree of impact of EE on Altruism $\left(\mathrm{Y}_{1}\right)$ in Panel A, Sportsmanship $\left(\mathrm{Y}_{2}\right)$ in Panel B, Civic Virtue $\left(\mathrm{Y}_{3}\right)$ in Panel C, Courtesy $\left(\mathrm{Y}_{4}\right)$ in Panel D and Conscientiousness $\left(\mathrm{Y}_{5}\right)$ in Panel E. These regressions are represented in the following equation:

$\mathrm{Y}_{\mathrm{i}}=\mathrm{B}_{0}+\mathrm{B}_{1} \mathrm{X}_{1}+\mathrm{B}_{2} \mathrm{X}_{2}+\mathrm{B}_{3} \mathrm{X}_{3}+\mathrm{e}_{\mathrm{i}}$

Where: $\mathrm{Y}_{1}$ : Altruism, $\mathrm{Y}_{2}$ : Sportsmanship, $\mathrm{Y}_{3}$ : Civic Virtue, $\mathrm{Y}_{4}$ : Courtesy, $\mathrm{Y}_{5}$ : Conscientiousness, $\mathrm{X}_{1}$ : Vigor, $\mathrm{X}_{2}$ : Dedication, $\mathrm{X}_{3}$ : Absorption, $\mathrm{B}_{0}, \mathrm{~B}_{1}, \mathrm{~B}_{2}, \mathrm{~B}_{3}$ : Estimated Parameters

Table 5 Panel A: Regression Model of EE on Altruism ( $\left.\mathrm{Y}_{1}\right)$

\begin{tabular}{llllll}
\hline & \multicolumn{2}{c}{ Model Abstract } & \multicolumn{2}{c}{ Model } \\
\cline { 2 - 5 } Independent Variable & $\mathrm{R}$ & $\mathrm{R}^{2}$ & F-value & $\mathrm{P}$ \\
\hline EE & .508 & .258 & 36.460 & .000 & $\begin{array}{l}\mathrm{Y}_{1}=2.203+.177 \mathrm{X}_{1} \\
+.113 \mathrm{X}_{2}{ }^{*}+.187 \mathrm{X}_{3}\end{array}$ \\
\hline
\end{tabular}

(*) variable non-significant

The results in Table 5 Panel A indicate that there is a direct significant impact of EE on Altruism. The value of the coefficient of determination $\left(\mathrm{R}^{2}\right)$ is .258 , which means that EE affects Altruism by $25.8 \%$ and the remaining $74.2 \%$ is explained by other variables. Also the F-value supports this effect since it is equal to 36.460 at a significance level less than 0.01. As a result we accept Hypothesis 1a: EE has a significant impact on Altruism.

Table 5 Panel B: Regression Model of EE on Sportsmanship ( $\left.\mathrm{Y}_{2}\right)$

\begin{tabular}{llcccc}
\hline & \multicolumn{2}{c}{ Model Abstract } & \multicolumn{2}{c}{ Model } \\
\cline { 2 - 5 } Independent Variable & $\mathrm{R}$ & $\mathrm{R}^{2}$ & F-value & $\mathrm{P}$ & \\
\hline $\mathrm{EE}$ & .422 & .178 & 22.658 & .000 & $\begin{array}{l}\mathrm{Y}_{2}=2.680+.020 \mathrm{X}_{1}^{(*)} \\
+.215 \mathrm{X}_{2}+.184 \mathrm{X}_{3}\end{array}$ \\
\hline
\end{tabular}

(*) variable non-significant 
The results in Table 5 Panel B indicate that there is a direct significant impact of EE on Sportsmanship. The value of the coefficient of determination $\left(\mathrm{R}^{2}\right)$ is .178 , which means that EE affects Sportsmanship by $17.8 \%$ and the remaining $82.2 \%$ is explained by other variables. Also the F-value supports this effect since it is equal to 22.658 at a significance level less than 0.01. As a result we accept Hypothesis 1b: EE has a significant impact on Sportsmanship.

Table 5 Panel C: Regression Model of EE on Civic Virtue $\left(\mathrm{Y}_{3}\right)$

\begin{tabular}{llllll}
\hline & \multicolumn{2}{c}{ Model Abstract } & \multicolumn{2}{c}{ Model } \\
\cline { 2 - 4 } Independent Variable & $\mathrm{R}$ & $\mathrm{R}^{2}$ & F-value & $\mathrm{P}$ & \\
\hline $\mathrm{EE}$ & .422 & .178 & 22.636 & .000 & $\begin{array}{c}\mathrm{Y}_{3}=2.496+.065 \mathrm{X}_{1}^{\left({ }^{*}\right)} \\
+.160 \mathrm{X}_{2}+.167 \mathrm{X}_{3}\end{array}$ \\
\hline
\end{tabular}

(*) variable non-significant

The results in Table 5 Panel $\mathrm{C}$ indicate that there is a direct significant impact of EE on Civic Virtue. The value of the coefficient of determination $\left(\mathrm{R}^{2}\right)$ is .178 , which means that EE affects Civic Virtue by $17.8 \%$ and the remaining $82.2 \%$ is explained by other variables. Also the F-value supports this effect since it is equal to 22.636 at a significance level less than 0.01. As a result we accept Hypothesis 1c: EE has a significant impact on Civic Virtue.

Table 5 Panel D: Regression Model of EE on Courtesy $\left(\mathrm{Y}_{4}\right)$

\begin{tabular}{lllcll}
\hline & \multicolumn{2}{c}{ Model Abstract } & \multicolumn{3}{c}{ Model } \\
\cline { 2 - 5 } Independent Variable & $\mathrm{R}$ & $\mathrm{R}^{2}$ & F-value & $\mathrm{P}$ & \\
\hline $\mathrm{EE}$ & .391 & .153 & 18.917 & $.000 \begin{array}{c}\mathrm{Y}_{4}=3.839-.448 \mathrm{X}_{1} \\
+.047 \mathrm{X}_{2}{ }^{(*)}+.002 \mathrm{X}_{3}{ }^{(*)}\end{array}$ \\
\hline
\end{tabular}

(*) variable non-significant

The results in Table 5 Panel D indicate that there is a direct significant impact of EE on Courtesy. The value of the coefficient of determination $\left(\mathrm{R}^{2}\right)$ is .153 , which means that EE affects Courtesy by $15.3 \%$ and the remaining $84.7 \%$ is explained by other variables. Also the F-value supports this effect since it is equal to 18.917 at a significance level less than 0.01. As a result we accept Hypothesis 1d: EE has a significant impact on Courtesy.

Table 5 Panel E: Regression Model of EE on Conscientiousness $\left(\mathrm{Y}_{5}\right)$

\begin{tabular}{llcccc}
\hline & \multicolumn{2}{c}{ Model Abstract } & \multicolumn{2}{c}{ Model } \\
\cline { 2 - 5 } Independent Variable & $\mathrm{R}$ & $\mathrm{R}^{2}$ & F-value & $\mathrm{P}$ & \\
\hline EE & .458 & .210 & 27.793 & .000 & $\begin{array}{c}\mathrm{Y}_{5}=1.459+.175 \mathrm{X}_{1}^{\left({ }^{*}\right)} \\
+.042 \mathrm{X}_{2}{ }^{(*)}+.306 \mathrm{X}_{3}\end{array}$ \\
\hline
\end{tabular}

(*) variable non-significant

The results in Table 5 Panel $\mathrm{E}$ indicate that there is a direct significant impact of EE on Conscientiousness. The value of the coefficient of determination $\left(\mathrm{R}^{2}\right)$ is .210 , which means that EE affects Conscientiousness by $21 \%$ and the remaining $79 \%$ is explained by other variables. Also the F-value supports this effect since it is equal to 27.793 at a significance level less than 0.01. As a result we accept Hypothesis 1e: EE has a significant impact on Conscientiousness.

From the above results it is clear that we accept Hypothesis 1: Employee Engagement has a significant impact on Organizational Citizenship Behaviour for faculty members at Ain Shams University.

\subsection{Robustness Check}

The authors check the correctness of accepting Hypothesis 1 by conducting a path analysis using (AMOS.20) to show the effect of EE represented in its three main dimensions on OCB that is represented in its five main dimensions. Structural equation modelling was used to test the overall consistency of the proposed model. Table 6 represents the path coefficients for the structural equation model. 
Table 6. Path Coefficients for the Structural Equation Model

\begin{tabular}{|c|c|c|c|c|c|c|c|}
\hline Path Coefficients & & & Estimate & $\begin{array}{l}\text { Standardized } \\
\text { Estimate }\end{array}$ & S.E & C.R. & $P$ value \\
\hline Altruism & $<--$ & Vigor & .177 & .215 & .072 & 2.454 & .014 \\
\hline Sportsmanship & $<--$ & Vigor & .020 & .022 & .082 & .242 & .809 \\
\hline Civic virtue & $<--$ & Vigor & .065 & .077 & .076 & .861 & .389 \\
\hline Courtesy & $<--$ & Vigor & -.448 & -.419 & .091 & -4.910 & .000 \\
\hline Conscientiousness & $<--$ & Vigor & .175 & .165 & .093 & 1.880 & .060 \\
\hline Altruism & $<--$ & Dedication & .113 & .146 & .063 & 1.815 & .070 \\
\hline Sportsmanship & $<--$ & Dedication & .215 & .245 & .072 & 3.011 & .003 \\
\hline Civic virtue & $<--$ & Dedication & .160 & .199 & .066 & 2.429 & .015 \\
\hline Courtesy & $<--$ & Dedication & .047 & .046 & .079 & .590 & .555 \\
\hline Conscientiousness & $<---$ & Dedication & .042 & .042 & .081 & .521 & .602 \\
\hline Altruism & $<--$ & Absorption & .187 & .247 & .064 & 2.943 & .003 \\
\hline Sportsmanship & $<---$ & Absorption & .184 & .214 & .073 & 2.524 & .012 \\
\hline Civic virtue & $<---$ & Absorption & .167 & .213 & .067 & 2.486 & .013 \\
\hline Courtesy & $<---$ & Absorption & .002 & .002 & .081 & .019 & .985 \\
\hline Conscientiousness & $<---$ & Absorption & .306 & .312 & .082 & 3.715 & .000 \\
\hline
\end{tabular}

The regression weight for Vigor in the prediction of Altruism and Courtesy is significantly different from zero at the 0.05 and 0.01 levels respectively. The regression weight for Dedication in the prediction of Sportsmanship and Civic Virtue is significantly different from zero at the 0.01 and 0.05 levels respectively. The regression weight for Absorption in the prediction of Altruism, Sportsmanship, Civic Virtue and Conscientiousness is significantly different from zero at the $0.01,0.05,0.05$ and 0.01 levels respectively. In addition, Table 7 represents the total effect, the direct effect and the indirect effect between the three EE dimensions $\left(\mathrm{X}_{1}\right.$ : Vigor, $\mathrm{X}_{2}$ : Dedication, $\mathrm{X}_{3}$ : Absorption) and the five OCB dimensions (Altruism, Sportsmanship, Civic Virtue, Courtesy and Conscientiousness) in the structured model (Hemakumara, Khatibi, and Johar, 2019).

Table 7. Total, Direct and Indirect Effects between the Main Variables in the Structured Model

\begin{tabular}{lllllllllll}
\hline & \multicolumn{1}{c}{ Total Effects } & \multicolumn{3}{c}{ Direct Effects } & \multicolumn{3}{c}{ Indirect Effects } \\
\hline \multirow{3}{*}{ Altruism } & $\mathrm{X}_{1}$ & $\mathrm{X}_{2}$ & $\mathrm{X}_{3}$ & $\mathrm{X}_{1}$ & $\mathrm{X}_{2}$ & $\mathrm{X}_{3}$ & $\mathrm{X}_{1}$ & $\mathrm{X}_{2}$ & $\mathrm{X}_{3}$ \\
Sportsmanship & .215 & .146 & .247 & .215 & .146 & .247 & & .000 & .000 & .000 \\
Civic virtue & .022 & .245 & .214 & .022 & .245 & .214 & .000 & .000 & .000 \\
Courtesy & .077 & .199 & .213 & .077 & .199 & .213 & .000 & .000 & .000 \\
Conscientiousness & -.419 & .046 & .002 & -.419 & .046 & .002 & .000 & .000 & .000 \\
& .165 & .042 & .312 & .165 & .042 & .312 & .000 & .000 & .000
\end{tabular}

The researchers tested the proposed model by using structural equation modelling, which tests the model path coefficients by taking into account the measurement errors and the indirect relations. The results from the robustness checks in both Table 6 and Table 7 showed that the overall consistency of the proposed model is high. As a result, the decision to accept Hypothesis 1 is correct.

\section{Discussion and Conclusion}

Both EE and OCB are similar in that they are individual behaviours that are required within the workplace and are considered important for the development and maintenance of the employee-organizational relationship. The main distinction between the two concepts is that EE is considered as an antecedent that will cause and lead to OCB. EE represents an energized workforce that focuses on expression of the employee's self while performing his/her role activities. EE reflects the psychological wellbeing of the employee (Aselage and Eisenberger, 2003). OCB, on the 
other hand, represents the level of immersion in work the employees feel that they forget anything else and they truly become citizens of the organization, i.e., that they have duties towards it as well as their rights.

The results indicate that we accept Hypothesis 1: Employee Engagement has a significant impact on Organizational Citizenship Behaviour for faculty members at Ain Shams University. The contribution of the study is that it is conducted in an Arab/Middle Eastern country. The study also examines the effect of EE on OCB in the academic arena (an Egyptian public university), while most of the previous studies examining the effect of EE on OCB were conducted on for-profit corporations.

\subsection{Future Research}

Comparative studies should be conducted between public universities and private universities in Egypt. This study should be replicated in a private university in Egypt to see if the results are similar. More studies should be conducted on EE and its relationship with other individual factors such as emotional intelligence (Aselage and Eisenberger, 2003). Future researchers should conduct the same research while taking into consideration the effect of both peers assessment and supervisor's ratings, in addition to the self- assessment questionnaire that was used in this study.

\subsection{Limitations}

The field of study is limited only to one Egyptian public university. Female faculty members dominate the sample $(67.3 \%)$. This could skew the responses to the questionnaires. $83.1 \%$ of the respondents were 40 years or younger ( $42.8 \%$ between 30 and 40 years old and $40.3 \%$ were 30 years old or younger). The sample being dominated by early stage and mid-stage faculty members could possibly bias the results.

\section{References}

Abraham, S. (2012). Job satisfaction as an antecedent to employee engagement. SIES Journal of Management, 8(2), 27-36.

Ariani, D. (2013). The relationship between employee engagement, organizational citizenship behaviour, and counterproductive work behaviour. International Journal of Business Administration, 4(2), 46-56. https://doi.org/10.5430/ijba.v4n2p46

Aronson, K., Laurenceau, J., Sieveking, N., \& Bellet, W. (2005). Job satisfaction as a function of job level. Administration and Policy in Mental Health Services Research, 32(3), 285-291. https://doi.org/10.1007/s10488-004-0845-2

Aselage, J., \& Eisenberger, R. (2003). Perceived organisational support and psychological contracts: a theoretical integration. Journal of Organizational Behaviour, 24(5), 491-509. https://doi.org/10.1002/job.211

Asgari, A., Silong, A., Ahmad, A., \& Abu Samah, B. (2008). The relationship between transformational leadership behaviours, organizational justice, leader-member exchange, perceived organizational support, trust in management and organizational citizenship behaviours", European Journal of Scientific Research, 23(2), 227-242.

Atkinson, J. (1964). Introduction to motivation. Princeton, NJ: Van Nostrand.

Avery, D., McKay, P., \& Wilson, D. (2007). Engaging the aging workforce: the relationship between perceived age similarity, satisfaction with co-worker and employee engagement. Journal of Applied Psychology, 25(9), 1542-1556. https://doi.org/10.1037/0021-9010.92.6.1542

Ayatse, F., \& Ikyanyon, D. (2012). Organizational communication, job stress and citizenship behaviour of IT employees in Nigerian universities. Journal of Business Administration Research, 1(1), 99-105. https://doi.org/10.5430/jbar.v1n1p99

Azar, M. (2018). The impact of job characteristics on organizational citizenship behavior. International Journal of Business and Management Invention, 7(2), 54-57.

Babcock-Roberson, M., \& Strickland, O. (2010). The relationship between charismatic leadership, work engagement, and organizational citizenship behaviours. Journal of Psychology, 144(3), 313-326. https://doi.org/10.1080/00223981003648336

Bachrach, D., Bendoly, E. \& Podsakoff, P. (2001). Attributions of the "causes" of group performance as an alternative explanation of the relationship between organizational citizenship behaviour and organizational performance. Journal of Applied Psychology, 86(6), 1285-1293. https://dx.doi.org/10.1037/00219010.86.6.1285 
Bakker, A. (2005). Flow among music teachers and their students: the crossover of peak experiences. Journal of Vocational Behaviour, 66, 26-44. https://dx.doi.org/10.1016/j.jvb.2003.11.001

Barkhuizen, N., \& Rothmann, S. (2006). Work engagement of academic staff in South African higher education institutions. Management Dynamics, 15(1), 38-46.

Bates, S. (2004). Getting Engaged. HR Magazine, 49(2), 44-51.

Berger, B. (2008). Employee / Organizational communication. Institute of Public Relations, 15, 1-15.

Breevaart, K., Bakker, A., \& Demerouti, E. (2014). Daily self-management and employee work engagement. Journal of Vocational Behaviour, 84(1), 31-38. http://dx.doi.org/10.1016/j.jvb.2013.11.002

Brown, S., \& Leigh, T. (1996). A new look at psychological climate and its relationship to job involvement, effort, and performance. Journal of Applied Psychology, 81(4), 359-368. https://dx.doi.org/10.1037/0021-9010.81.4.358

Colquitt, J. (2001). On the dimensionality of organizational justice: a construct validation of a measure. Journal of Applied psychology, 86(3), 386-400. https://dx.doi.org/10.1037//0021-9010.86.3.386

Cooper-Hakim, A. \& Viswesvaran, C. (2005). The construct of work commitment: testing an integrative framework. Psychological Bulletin, 131, 241-259. https://dx.doi.org/10.1037/0033-2909.131.2.241

Gonzalez-Roma, V., Schaufeli, W., \& Bakker, A. (2006). Burnout and work engagement: independent factors or opposite poles? Journal of Vocational Behaviour, 68, 165-174. https://dx.doi.org/10.1016/j.jvb.2005.01.003

Harter, J., Schmidt, F., \& Hayes, T. (2002). Business-unit level relationship between employee satisfaction, employee engagement and business outcomes: a meta-analysis. Journal of Applied Psychology, 87(2), 268-279. https://dx.doi.org/10.1037//0021-9010.87.2.268

Hemakumara M., Khatibi A., \& Johar M. (2019). Organizational citizenship behaviour among administrative staff of state universities in Sri Lanka. International Journal of Arts and Commerce, 8(1), 16-21.

Ibrahim, R., Abd Ghani, M., \& Embat, A. (2013). Organizational citizenship behaviours among local government employees in east coast Malaysia: a pilot study. International Business Research, 6(6), 83-94. http://dx.doi.org/10.5539/ass.v9n13p92

Javadi, M., \& Yavarian, J. (2011). Effect of organizational identity and commitment on organizational citizenship behaviour (case study: Educational department of Isfahan province). Interdisciplinary Journal of Contemporary Research in Business, 3(2), 100-112.

Jung, D., \& Avolio, B. (2000). Opening the black box: an experimental investigation of the mediating effects of trust and value congruence on transformational and transactional leadership. Journal of Organizational Behaviour, 21(8), 949-964. https://doi.org/10.1002/1099-1379(200012)21:8<949::AID-JOB64>3.0.CO;2-F

Kaliannan, M., \& Adjovu, S. (2015). Effective employee engagement and organizational success: a case study. Social and Behavioural Sciences, 172, 161-168. https://doi.org/10.1016/j.sbspro.2015.01.350

Kandlousi, N., Ali, A., \& Abdollahi, A. (2010). Organizational citizenship Behaviour in concern of communication satisfaction: the role of the formal and informal communication. International Journal of Business and Management, 5(10), 51- 61. https://doi.org/10.5539/ijbm.v5n10p51

Kataria, A., Garg, P., \& Rastogi, R. (2013). Employee engagement and organizational effectiveness: the role of organizational citizenship behaviour. International Journal of Business Insights and Transformation, 6(1), $102-113$.

Klein, W. (2003). Effects of objective feedback and "single other" or "average other" social comparison feedback on performance judgments and helping behaviour. Personality and Social Psychology Bulletin, 29, 418-429. http://dx.doi.org/10.1177/0146167203251195

Kolade, O., Oluseye, O., \& Omotayo, A. (2014). Organizational citizenship behaviour, hospital corporate image and performance. Journal of Competitiveness, 6(1), 36-49. https://doi.org/10.7441/joc.2014.01.03

Krishnan, V. (2005). Transformational leadership and outcomes: role of relationship duration. Leadership \& Organization Development Journal, 26(6), 442-457. https://doi.org/10.1108/01437730510617654

Lakshmi G. (2012). Employee engagement- a corporate boon: 10 ways for effective engagement. Advances in Management, 5(2), 64-65. 
Langelaan, S., Bakker, A., Van Doornen, L. \& Schaufali, W. (2006). Burnout and work engagement: do individual differences make a difference? Personality and Individual Differences, 40, 521-532. https://doi.org/10.1016/j.paid.2005.07.009

Lee, K., \& Allen, N. (2002). Organizational citizenship behaviour and workplace deviance: the role of affect and cognitions. Journal of Applied Psychology, 87(1), 131-142. http://dx.doi.org/10.1037/0021-9010.87.1.131

Lee, U., Kim, H., \& Kim, Y. (2013). Determinants of organizational citizenship behaviour and its outcomes. Global Business and Management Research: An International Journal, 5(1), 54-65.

Little, B., \& Little, P. (2006). Employee engagement: conceptual issues. Journal of Organizational Culture, Communication, and Conflict, 10(1), 111-120.

Llorens, S., Shaufeli, W., Bakker, A. \& Salanova, M. (2007). Does a positive gain spiral of resources, efficacy beliefs and engagement exist? Computers in Human Behaviour, 23, 825-841. https://doi.org/10.1016/j.chb.2004.11.012

Lloyd, R. (2008). Discretionary effort and the performance domain. The Australian and New Zealand Journal of Organizational Psychology, 1, 22-34. https://doi.org/10.1375/ajop.1.1.22

Macey, W., \& Schneider, B. (2008). The meaning of employee engagement. Industrial and Organizational Psychology, 1, 3-30. https://doi.org/10.1111/j.1754-9434.2007.0002.x

Markos, S., \& Sridevi, M. (2010). Employee engagement: the key to improving performance. International Journal of Business Management, 5(12), 89-96. https://doi.org/10.5539/ijbm.v5n12p89

Maslach, C., Schaufeli, W., \& Leiter, M. (2001). Job burnout. Annual Review of Psychology, 52, 397-422. https://doi.org/10.1146/annurev.psych.52.1.397

Mauno, S., Kinnunen, U., \& Ruokolainen, M. (2007). Job demands and resources as antecedents of work engagement: a longitudinal study. Journal of Vocational Behaviour, 70(1), 149-171. https://doi.org/10.1016/j.jvb.2006.09.002

May, D., Gilson, R., \& Harter, L., (2004). The psychological conditions of meaningfulness, safety, and availability and the engagement of the human spirit at work. Journal of Occupational and Organizational Psychology, 77, 11-37. https://doi.org/10.1348/096317904322915892

Miles, D., Spector, P., Borman, W., \& Fox, S. (2002). Building an integrative model of extra role work behaviour: a comparison of counterproductive work behaviour with organizational citizenship behaviour. International Journal of Selection and Assessment, 10(1/2), 51-57. https://doi.org/10.1111/1468-2389.00193

Mohammad, J., Habib, F., \& Alias, M. (2011). Job satisfaction and organizational citizenship behaviour: an empirical study at higher learning institutions. Asian Academy of Management Journal, 16(2), 149-165.

Muhammad, A. (2004). Procedural justice as mediator between participation in decision-making and organizational citizenship behaviour. International Journal of Commerce \& Management, 14(3/4), 58-68. https://doi.org/10.1108/10569210480000184

Murphy S., \& Ensher, E. (2001). The role of mentoring support and self-management strategies on reported career outcomes. Journal of Career development, 27, 229-246. https://doi.org/10.1177/089484530102700401

Murphy, G., Athanasou, J., \& King, N. (2002). Job satisfaction and organizational citizenship behaviour: a study of Australian human-service professionals. Journal of Managerial Psychology, 17(4), 287-297. http://dx.doi.org/10.1108/02683940210428092

Organ, D. (1988). Organizational citizenship behaviour: the good soldier syndrome. Lexington, MA: Lexington Books.

Organ, D. (1997). Organizational citizenship behaviour: it's construct clean-up time. Human Performance, 10(2), 85-97. https://doi.org/10.1207/s15327043hup1002_2

Organ, D., Podsakoff, P., \& MacKenzie, S. (2006). Organizational citizenship behaviour: its nature, antecedents, and consequences. Thousand Oaks, CA: Sage Publications, Inc.

Organ, D., \& Ryan, K. (1995). A meta-analytic review of attitudinal and dispositional predictors of organizational citizenship behaviour. Personnel Psychology, 48, 775-802. https://doi.org/10.1111/j.1744-6570.1995.tb01781.x 
Podsakoff, P., MacKenzie, S., Paine, J., \& Bachrach, D. (2000). Organizational citizenship behaviours: a critical review of the theoretical and empirical literature and suggestions for future research. Journal of Management, 26(3), 513-563. https://doi.org/10.1177/014920630002600307

Podsakoff, P., MacKenzie, S., Moorman, R., \& Fetter, R. (1990). Transformational leader behaviours and their effects on followers' trust in leader, satisfaction, and organizational citizenship behaviours. Leadership Quarterly, 1(2), 107-142. https://doi.org/10.1016/1048-9843(90)90009-7

Raabe, B., Frese, M. \& Becher, T. (2007). Action regulation theory and career self-management. Journal of Vocational Behaviour, 70, 297-311. https://doi.org/10.1016/j.jvb.2006.10.005

Rasheed, A., Jehanzeb, K., \& Rasheed, M. (2013). An investigation of the antecedents oforganizational citizenship behaviour: case of Saudi Arabia. International Journal of Psychological Studies, 5(1), 128-138. https://doi.org/10.5539/ijps.v5n1p128

Resick, C., Baltes, B., \& Shantz, C. (2007). Person-organization fit and work-related attitudes and decisions: examining interactive effects with job fit and conscientiousness. Journal of Applied Psychology, 92(5), 1446-1455. https://doi.org/10.1037/0021-9010.92.5.1446

Rhoades, L., \& Eisenberger, R. (2002). Perceived organizational support: a review of theliterature. Journal of Applied Psychology, 87(4), 698-714. https://doi.org/10.1037//0021-9010.87.4.698

Rioux, S., \& Penner, L. (2001). The causes of organizational citizenship behaviour: a motivational analysis. Journal of applied Psychology, 86(6), 1306-1314. http://dx.doi.org/10.1037/0021-9010.86.6.1306

Rose, K. (2012). Organizational citizenship behaviors in higher education: examining the relationships between behaviors and performance outcomes for individuals and institutions. Theses and Dissertations. 403. http://scholarworks.uark.edu/etd/403

Rurkkhum, S., \& Bartlett, K. (2012). The relationship between employee engagement and organizational citizenship behaviour in Thailand. Human Resource Development International, 15(2), 157-174. https://doi.org/10.1080/13678868.2012.664693

Sahafi, E., Danaee, H., Sariak, A., \& Haghollahi, F. (2011). The impact of emotional intelligence on citizenship behaviour of physicians (with emphasis on infertility specialists). Journal of Family and Reproductive Health, 5(4), 109-115.

Sahoo, C., \& Mishra, S. (2012). A framework towards employee engagement: the PSU experience. ASCI Journal of Management, 42(1), 94-112.

Saks, A. (2006). Antecedents and consequences of employee engagement. Journal of Managerial Psychology, 21(7), 600-619. https://doi.org/10.1108/02683940610690169

Schaufeli, W., \& Bakker, A. (2004). Job demands, job resources, and their relationship with burnout and engagement. Journal of Organizational Behavior, 25, 293-315. https://doi.org/10.1002/job.248

Schaufeli, W. \& Bakker, A. (2003). UWES: Utrecht Work Engagement Scale: Preliminary Manual. Occupational Health Psychology Unit, University of Utrecht. Available: https://www.academia.edu/31439118/UWES_UTRECHT_WORK_ENGAGEMENT_S

ALE_Preliminary_Manual (May10, 2019)

Schaufeli, W., Bakker, A., \& Salanova, M. (2006). The measurement of work engagement with a short questionnaire: a cross-national study. Educational and Psychological Measurement, 66(4), 701-716. https://doi.org/10.1177/0013164405282471

Schaufeli, W., Salanova, M., Gonzalez-Roma, V., \& Bakker, A. (2002). The measurement of engagement and burnout: a two sample confirmatory analytic approach. Journal of Happiness Studies, 3(1), 71-92. https://doi.org/10.1023/A:1015630930326

Shaw, K. (2005). An engagement strategy process for communicators. Strategic Communication Management, 9(3), 26-29.

Shuck, B., Reio Jr., T., \& Rocco, T. (2011). Employee engagement: an examination of antecedent and outcome variables. Human Resource Development International, 14(4), 427-445. https://doi.org/10.1080/13678868.2011.601587 
Soieb, A., Othman, J., \& D’Silva, J. (2013). The effects of perceived leadership styles and organizational citizenship behaviour on employee engagement: the mediating role of conflict management. International Journal of Business and Management, 8(8), 91-99. https://doi.org/10.5539/ijbm.v8n8p91

Smith, C., Organ, D., \& Near, J. (1983). Organizational citizenship behaviour: its nature and antecedents. Journal of Applied Psychology, 68, 655-663. http://dx.doi.org/10.1037/0021-9010.68.4.653

Sun, L., Aryee, S. \& Law, K. (2007). High-performance human resource practices, citizenship behaviour and organizational performance: a relational perspective. The Academy of Management Journal Archive, 50(3), 558-577. https://doi.org/10.5465/AMJ.2007.25525821

Zarea, H. (2012). Organizational citizenship behaviours and their relationship to social capital in public organizations of Qom province. Iranian Journal of Management Studies, 5(1), 79-96. https://doi.org/10.5296/ijhrs.v3i2.3991 